$$
\text { =シリーズテーマ= }
$$

\title{
細胞分化，遺伝情報の逐次的発現，シグナル伝達モデルとしての微生物
}

\begin{abstract}
細胞分化，遺伝情報の逐次的発現，シグナル伝達モデルとしての微生物…….....小林 泰夫…1781 枯草菌胞子形成初期遺伝子の発現制御 $\cdots \cdots \ldots \ldots \ldots \ldots \ldots \ldots \ldots \ldots \ldots \ldots \ldots \ldots \ldots \ldots \ldots \ldots \ldots \ldots$ 河村富士夫

大腸菌とネズミチフス菌の䩒毛レギュロンに物ける遗伝情報発現ネットワータ…沓掛 和弘…1790 放線菌における胞子形成・二次代謝産物合成亡遗伝情報癹現ネットワーク
\end{abstract}

.堀之内末治, 別府 輝彦…1795

酵母における遺伝情報発現のネットワータ 宇 野 功…1798

異坦子菌酵母の性分化：カルシウムイオンをセカンドィッセンジャーとする

情報カスケード

.宮川 都吉, 福井 作蔵…1802

\section{細胞分化，遺伝情報の逐次的発現，シグナル伝達 モデルとしての微生物†}

\author{
小 林 泰 夫 \\ (広島大学生物生産学部)
}

\section{はじめに}

微生物に就ける遗伝情報の逐次的発現や，外部シグナ ルの伝達については，大腸菌を中心に詳細な解析がなさ れてきたが，組換え DNA 技術の進展に伴って，1970 年代の後半から，枯草菌，酵母，さらには放線菌などを 中心とするさまざまな系での研究が進んできた。とくに 従来の手法ではありに居複雑で解析が不十分であった 細胞の分化機構や，遗伝情報伝達様式の解助 の系を用いて急速に発展しつつあるのは，特記すべきこ とであるう。

細胞分化は䍃密には，「多細胞系に括いて 1 個の細胞 の分裂に由来した娘細胞集団中で，形態的，機能的に質 的な差を持つ二つ以上のタイプの細胞が生してくる現象 をいう」(生物学辞典 (第 3 版), 岩波畫店, 1983) もの

1 Microorganism as a Model System for Differentiation, Sequential Gene Expression and Signal Transfer.

Yasuo KOBAYASHI (Faculty of Applied Biological Science, Hiroshima University, Higashi Hiroshima 724)
と考文られる。しかし近年，微生物に拈ける胞子やシス ト形成, ミクンバクテリア細胞性粘菌での多細胞構造 （子実体）の形成なども，単純化された細胞分化のモデル として盛えに研究されている。このよらな考充を初めて 取り入れたのは，筆者の知る限りでは Halvorsonではな いか子思ら(1)，その後，英国微生物学会のシンポジウム でこのテーマが取り上げられ，その内容は“Microbial Differentiation”といら本(2) として出版され，ての後も 同様な視点でまとめられたいくつかの成書がある（たと えば引用文献 (3)，(4)など).

徽生物に沶ける細胞分化の研究がこのように盛んにな ったのは，高等生物の系と異なり，取扱いが簡単で遗伝 学的, 生化学的解析が容易であるということにある。 そ の代表的な例が枯草菌 (Bacillus subtilis) の胞子形成で ある. 本レビューでは河村氏が胞子形成開始の調節機楧 を，小林が胞子形成過程に拈ける遗伝子の逐次的発現機

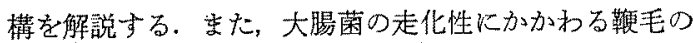
形成は，原核細胞におけるオルガネラ形成と，その遺伝 情報伝達の見事なネットワークといら観点からきわめて 
與味深い現象であるが，これについては沓掛氏に解説し ていたたいた，敖線菌は原核微生物のなかで最子複雑炕 分化した棈造を持つものの一つである。このような系で の遗伝情報の発現調節は，胞子形成や抗生物質などの二 次代謝産物の生成などと密接にからみ合い，きわわて複 雑な様相を是するが，組換え DNA 技術の発展によって 非常に多くのデータが蓄積されつつ市り，その一端を堀 之内，別府両氏にまとめていただいた

一方，ングナル伝達については，多くの研究が微生物 を用いて行われているが，今回は，遺伝学的，生化学的 解析の可能な，鼠す学練か力有用な真核生物として研究 の進んでいる醉母について，宇野氏に細胞增殖制御にか かわるシグナル伀達をG蛋白質，プロティンキナービを 中心に，また，宮川，福井両氏には，性分化に拈けるシ グナル伝達のカスケードについて最近明らがなった点 を中心に解説していただいた。

\section{枯草菌の胞子形成 $(5,6)$}

枯草菌は培地中の栄養源が枮渴してくると，菌体内に 胞子 (endospore) 形成する. 胞子形成は形態的, 生化 学的にはっきりと区別される7つの段階をへて進行する （図 1). 胞子形成の各段階に関与している胞子形成遺伝 子 (spo) は，約 50 種類知られて敊り，之の遺伝子に突 然変異が生じたとき，胞子形成がどの段階で停止するか Kよって, spoo, spoII, spoIII, spoIV, spoV, spoVI の6つのグルーブに大別される. 各グループはさらに $s p o 0 A ， s p o 0 B$ などいくつかの選伝子（またはオぺロン） から成り立っている。これらの遭伝子は染色体上に全く ランダムに散在しているが，これら遗伝子の逐次的発現 機構についての最近の知見を次に紹介する。

\section{胞子形成寈伝子の逐次的発現}

Mandelstam 占 ${ }^{(7)}$ ，胞子形成遗伝子に関寸る二重突 然変異株（たと完ば spooA と spoIIA の突然变異を持 つもの）を多数作成した。そ礼らが胞子形成のどの段愭

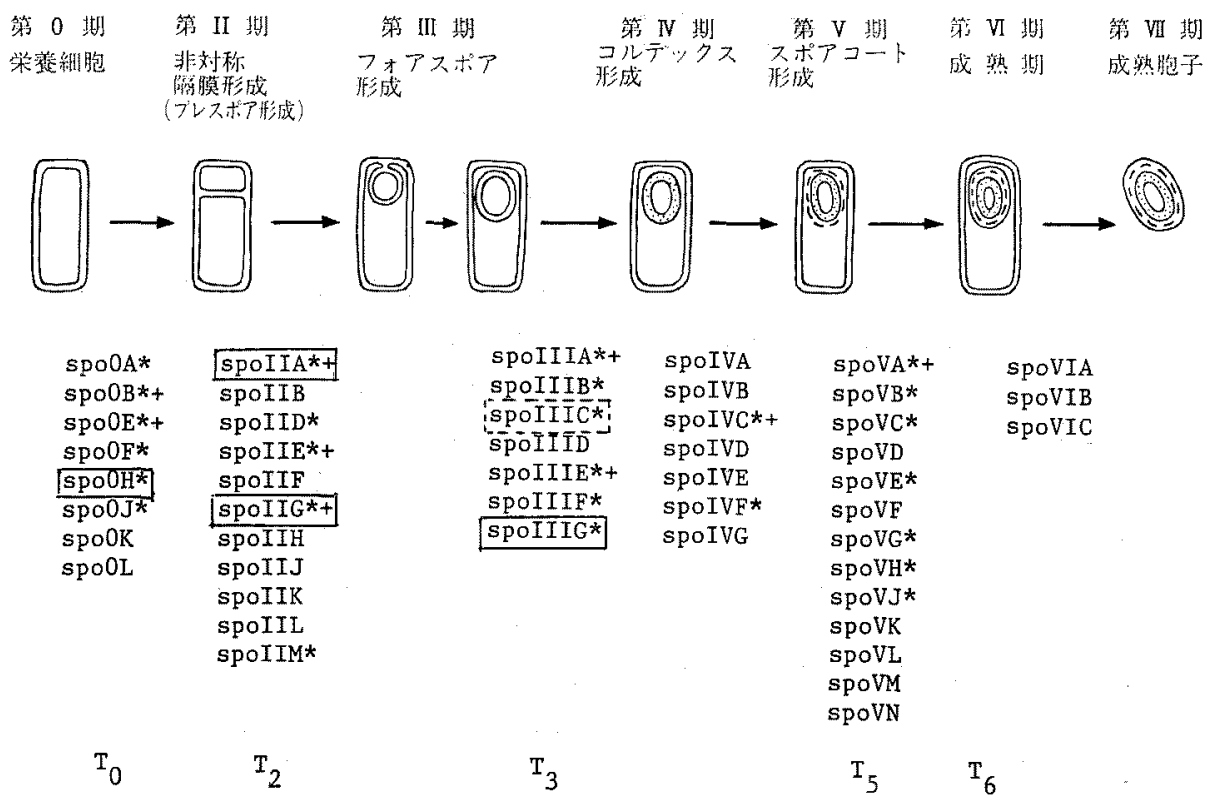

図 1 胞子形成過程の模式図と各過程に関与する胞子形成遗云子

第 0 期，栄養細胞；第II期，隔膜が細胞の一方に片寄って（非対称）形成され，その結果 2 つの コンパートメントができる.小さい注らをプレスポフ(将来胞子になる部分)，大きいほ5を母細胞 とい5; 第开期，プレスポアが細胞膜につつみ込まれフォアスポフとなる(三重膜の形成）；第 $\mathbb{N}$ 期，フォアスポフの二重膜の間にコルテックス(ペプチドグリカン）が沈着する; 第V期，フォア スポフの外部に母細胞で作られたスポアコート蛋白質が沈着する；第以期，成熟期；第䜣期，成熟

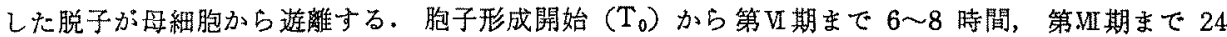
時間かかる.*，クローン化された䢙层子；十，2個以上の遗伝子からなるオぺロン；口，シダマ

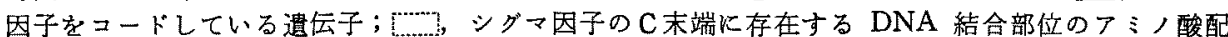
列とホモロジーを持っ蛋由筫をコードしている遭伝子， $\mathrm{T}_{\mathrm{n}}$ ，胞子形成開始後 $\mathrm{n}$ 時間を示す。 


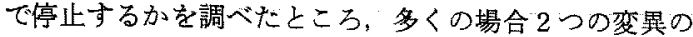
らちの早い活うの段階（たとえば spo0A，spoIIA 株で は第 0 期）で胞子形成が停止していた。このことは，胞 子形成過程は一連の逐次的過程であって，前の段階の遗 伝子の発現が抑えられると，去れ以後の遗伝子は発現さ れないことを示唆している.この点について Mandelstam と Errington ${ }^{(8)}$ は，多数のクローン化された胞子 形成遺层子を用いてさらに詳細な研究を行った。すなか ち、クローン化された胞子形成遗伝子とlacZ 遺伝子と の融合遗伝子を作成し、これを各種のspo 変異株染色体 に組み込んで， $\beta$ ーガラクトシダーゼ活性の発現と所在を 調べることにより，当該遗伝子が，母細胞で発現するの か,フォアスポアで発現するのか，また，その発現は胞 子形成期のどの時期に始京り，どの spo 遺云子に依存し ているのか在解析した：その結果，胞子形成遗伝子の胞 子形成期に怙讨る逐次的発現の骨格が明らかとなった (図 2).

\section{胞子形成遗伝子の発現とシグマ因子}

ところでこれらの spo 遺伝子の転写は, 胞子形成期の 枯草菌細胞に出現するいくつかのシグマ因子のカスケー ドによって行われていることが示唆されている，枯草菌 には 9 種類のシグマ因子が存在する(6) (图 3 ).こ机らの シグマ因子のうら $\sigma^{43}\left(\sigma^{A}\right)$ は, 枯草菌の主要なシグマ 因子であり，大腸菌の $\sigma^{70}$ に相当する，栄養細胞，胞子 形成期の細胞で機能する. $\sigma^{37}\left(\sigma^{\mathrm{B}}\right), \sigma^{32}\left(\sigma^{\mathrm{C}}\right), \sigma^{28}\left(\sigma^{\mathrm{D}}\right)$ はマイナーなシグマ因子で，栄養細胞に存在して特殊な 遺伝子の転写に関与していると考克られる。なかです
$\sigma^{28}\left(\sigma^{\mathrm{D}}\right)$ は，そのC末端のアミ酸配列が，大腸菌鞭毛 レギュロンの重要な調節因子である $A b B$ 遗伝子之相同 性が高く（沓掛の項参照），末たN末端頌域は $f l b B$ 遗云 子とオべロンを作っている flaI 遗伝子のアミ，酸配列

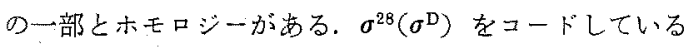
遺伝子 (sigD) に突然変買が起きると, 菌体は filamentousになりフラジェリンを合成できない：このことから $\sigma^{28}\left(\sigma^{\mathrm{D}}\right)$ は鞭毛レギュロンの発現比関与するシグマ因子 と考觉られている(日).

一方，胞子形成遗伝子の発現に関与するシグマ因子之 しては， $\sigma^{30}\left(\sigma^{\mathrm{H}}\right), \sigma^{29}\left(\sigma^{\mathrm{E}}\right)$, spoIIAC 遗伝子産物, spoIIIG 遺伝子産物 $\left(\sigma^{G}\right), \sigma^{27} の 5$ 種類分知られてい る. 胞子形成開始遗伝子のらちで, 最孔重要な役割を果 たしているのは，spo0A 遺伝子であるが(河村の項 参照), $s p o 0 A$ 遺伝子の発現飞は $s p o 0 H$ 遗伝子が 関与する. $s p o O H$ 遗伝子は $\sigma^{30}\left(\sigma^{\mathrm{H}}\right)$ をコードしてい るが，その活性は $\mathrm{T}$ 。で最高になり次第に低下する。 spoII AC 遺伝子の産物はシグマ因子 (SpoIIAC) で, この遗伝子に突然変異が起こると胞子形成は第正期で停 止する. spoIIAC 遗伝子の発現には spooH が必要て あるが, spoIIG は不要である. spoIIAC 遗伝子は $\mathrm{E} \sigma^{43}\left(\mathrm{E} \sigma^{\mathrm{A}}\right)$ ( $\mathrm{E}:$ コア酵素) に上って転写されるが，そ の転写にはspoIIF, spoIIM が必要である（図2 参 照).

spoIIG オペロンはspoIIGA とspoIIGB 遗伝子と からなる。. $\sigma^{29}\left(\sigma^{\mathrm{E}}\right)$ はspoIIGB 遺伝子の産物で市 り， $\mathrm{T}_{2} \sim \mathrm{T}_{4}$ 期の細胞に存在する. spoIIG オペロン

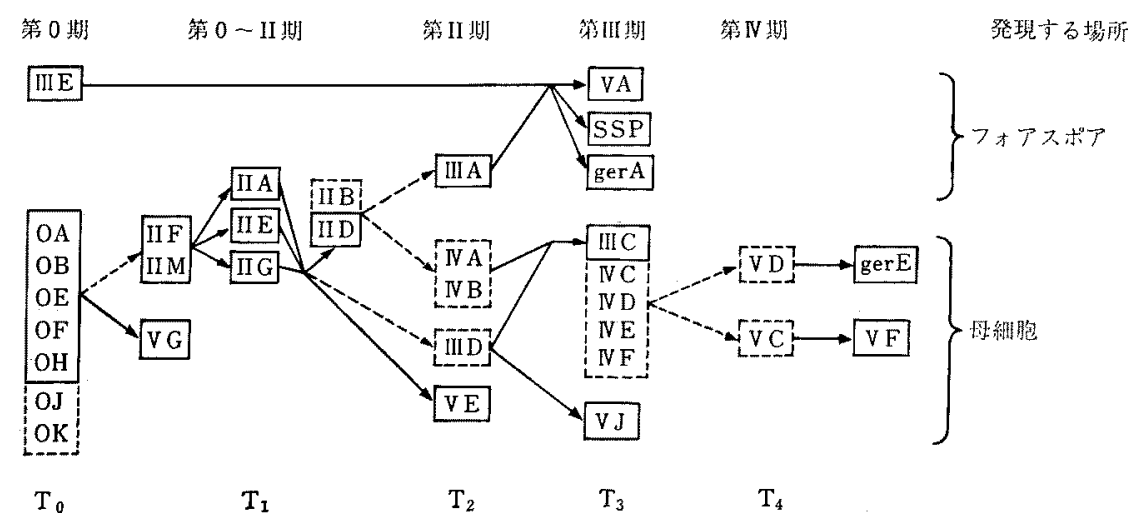

图 2 胞子形成期に打的胞子形成遗伝子の逐次的発現之局在化

実線で畐まれた遺伝子は直接その発現が調ぺられたすの。点線で国まれた遗伝子は直接発現が測 定されていないるの.実線は依存性が直接測定されたのの.点線は依存性が示唆されるが, 直接測 定されていないるの. 


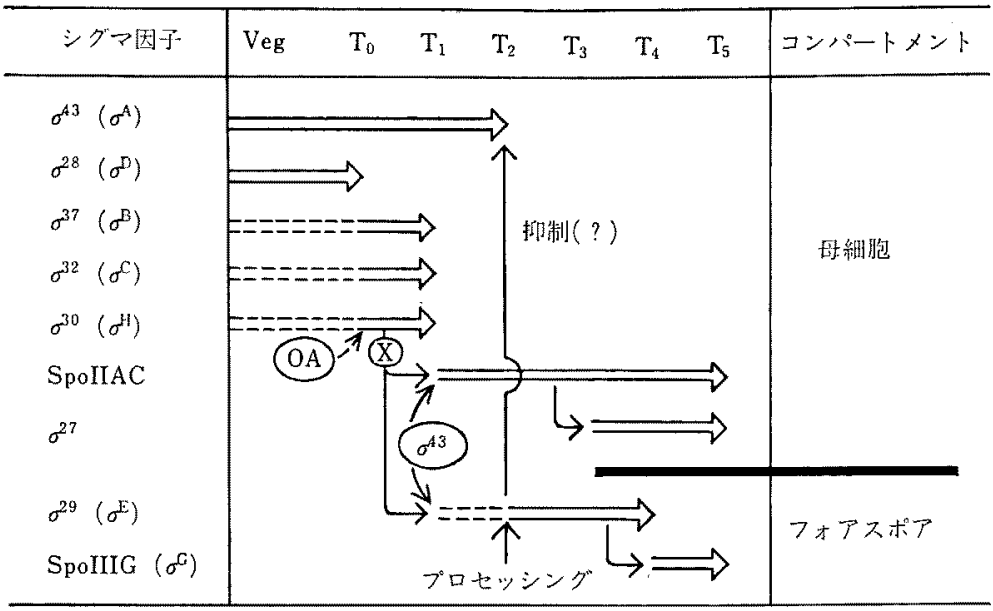

図 3 胞子形成期におけるシグマ因子のカスケードと局在化

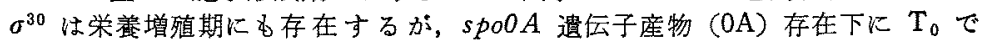
発現が最大となる。太い矢印はシグマ因子活性が存在する時期を示す、細い知印 はカスケードの流れを示す，上位のシグマ因子の発現が下位のシグマ因子の発現 沉必要であるが，これは必ずしも上位のシグマ因子を含むホ口醉素が直接下位の

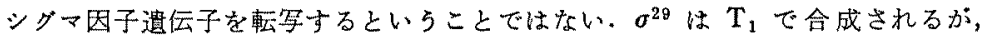
$\mathrm{T}_{2}$ でプロセスされて活性化する(本文参照). $\mathrm{E} \sigma^{29}$ は $\mathrm{E} \sigma^{43}$ を不活化すると考 えられている. spoIIAC \& spoIIG 遗伝子は $\mathrm{E} \sigma^{43}$ で転写されるが，そのため にはspoIIF（执よびspoIIM）必要とする。X：正の調節因子(spoIIF未 たは spoIIM 遗伝子産物?)

は $\mathrm{E} \sigma^{43}\left(\mathrm{E} \sigma^{\mathrm{A}}\right)$ によって転写されるが，その転写には $s p o I I A C$ 遺伝子“同様, spoIIF, spoIIM 遗伝子産 物が必要である. spoIIGB 遗伝子の直接の産物は pro- $\sigma^{\mathrm{E}}$ であり，そのN末端の 29 個のアミノ酸のプロ 七ッシンク゚によって, 初めて活性のある $\sigma^{29}\left(\sigma^{\mathrm{E}}\right)$ とな る. spoIIGA 遺伝子産物の $\mathrm{N}$ 末端側は非常に疎水性 で, 5つの membrane spanning 領域を有し，C末端 側は親水性である. spoIIGA 变異株ではpro- $\sigma^{\mathrm{E}} の$ プロセッシングが起こらず，pro- $\sigma^{\mathrm{E}}$ が蓄積する。この ことから Stragier $ら^{(10)}$ は, spoIIGA 産物は膜結合

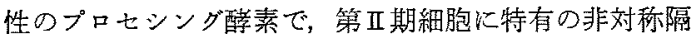
膜に組み这礼ることによって，初めて活性化し，pro$\sigma^{\mathrm{E}}$ をプロ七スすると考えた。このことにより，胞子形 成第 II 期の非対称事膜形成之 $\sigma^{29}\left(\sigma^{\mathrm{E}}\right)$ の活性化がきか めて厳密にカップルした，遗伝子発現調節機構のモデル を提晿した。

最近，spoIIGB 遺伝子の下流にシグマ因子によく似 たアミ，酸配列を持つ蛋白質をコードしているオープン リーディングフレイム（spoIIG ORF 3) が見出され た(11).この遺伝子の産物がシグマ因子であることが， Stragier ら; Setlow らのグループにより in vitro で確
認された（第 10 回国際胞子会議、Mar., 1988, Woods Hole, Mass., U.S.A.). この ORF は spoIIIG と命名 され，新しいシグマ因子は $\sigma^{\mathrm{a}}$ と命名された. spoIIIG 遺伝子は $\mathrm{T}_{4}$ 以降つ*アスポアで発現し sspE, spoVA 遺 公子の転写に必要である.これとは全く別に, Losick ら は胞子形成後期の細胞中に $\sigma^{27}$ (分子量 27,000 ) と名付 けた全く新しいシグマ因子が存在することを見出した (第 10 回国際胞子会議，同上). $E \sigma^{27}$ による胞子形成後 期遺伝子の逐次的発現样式はき初めて興味深い. $\mathrm{E} \sigma^{27}$ は in vivoで spoIVC 遗伝子を転写するが，そのためには 分子量 14,000 の蛋白質 $(14 \mathrm{~K})$ が必要である. $14 \mathrm{~K}$ 蛋 白質がないと spoIVC 遗伝子の転写は抑制され，代っ て $\cot A, \cot D$ というスポアコート蛋白質をコードして いる遗伝子が転写される. 李大 $14 \mathrm{~K}$ 蛋白質が存在する 之, $\cot A, \cot D$ は転写されない，一方，in vivo の実験 加 5 gerE 遗质子産物は $\cot A, \cot D$ の転写を抑充 $\cot C$ 遺伝子の発現に必要である(12).これらの結果および $s p o I V C, \cot A, \cot D, g e r E, \cot C$ 遗伝子の発現時期少 5 Losick bは, 胞子形成後期遗伝子の発現と形態形成 とをカップリングさせた仮説を提唱した（図4）（第 10 回国際胞子会議，同上).まず $14 \mathrm{~K}$ 蛋白質が出現し $\sigma^{27}$ 
a）選伝子の発現時期

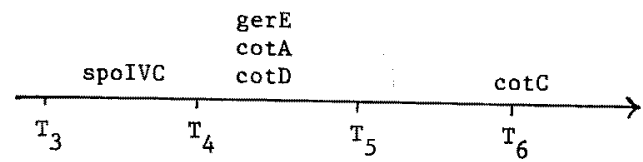

b) $14 \mathrm{~K}$ 蛋白筧，GerE蛋白筫の作用機作

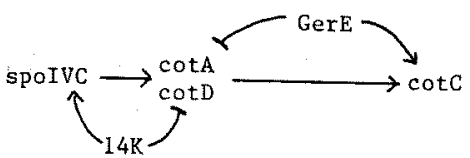

図 4 後期胞子形成遺后子の発現調節モデル

$14 \mathrm{~K}$ 蛋白質は $\mathrm{E}^{27}$ ととbにspoIVC 遗伝子 の転写を促進するが, $\cot A, \cot D$ 遺厷子の発現を 抑える. GerE 蛋白質は $\cot A(\cot D)$ 遗伝子の発 現を抑觉るが， $\cot C$ 掼层子の発現は促進する。

ととを 質が消失（たと竞ば，スポアコートへの組込み）すると $s p o I V C$ 遺伝子の発現は停止し $\cot A, \cot D$ 遺伝子加転 写され，次に gerE 遗伝子が発現すると $\cot A$ が抑觉ら れ $\cot C$ の発現が促進される.このように形態形成とカ ップルした遗伝子発現調節機搆は，大晹菌鞭毛レギュロ ソの $\mathrm{flaU}$ 遺伝子の発現(13) で示唆されていたが（沓掛の 項参照)，枯草菌の胞子形成過程において子，同様の調 節機構を示唆する結果が $s p o L I G$ オペロンやスポアコ 一ト蛋白質遗伝子の発現調節に拈いて示されたことは， 細胞分化における形態形成とカップルした遗伝子癹現調 節機構の普遍性を示唆するすのとして興味深いこえら の調節機構の実態を明らかにすることが，今後の重要な 研究課題であろう.
(1) H.O. Halvorson: "Function and Structure in Microorganisms, "The 15 th Symposium of the Society for General Microbiology, Cambridge University Press, Cambridge, 1965, p. 343 .

(2) J.M. Ashworth and J.E. Smith (ed.): "Microbial Differentiation," The 23 rd Symposium of the Society for General Microbiology, Cambridge University Press, Cambridge, 1973.

(3) R. Losick and L. Shapiro (ed.): "Microbial Development, " Cold Spring Harbor Laboratory, New York, 1984.

(14) J.A. Hoch and P. Setlow (ed.): "Molecular Biology of Microbial Differentiation," American Society for Microbiology, Washington, D. C., 1985.

(5) R. Losick, P. Youngman and P.J. Piggot: Annu. Rev. Genet., 20, 625 (1986).

(6) Y.Kobayashi : "Bacillus subtilis-Molecular Biology and Its Industrial Application," ed. by B. Maruo and H. Yoshikawa, Kohdansha Scientific, Tokyo, in press.

(7) J.G. Coote and J. Mandelstam : J. Bacteriol., 114, 1254 (1973).

(8) J. Mandelstam and J. Errington : Microbiol. Sci., 4, 238 (1987).

(9) J. D. Helmann, L. M. Mároquez and M.J. Chamberlin : J. Bacteriol., 170, 1568(1988).

(10) P.Stragier, C. Bonamy and C. KaramazynCampelli : Cell, 52, 697 (1988).

(11) E.S. Masuda, H. Anaguchi, K. Yamada and Y. Kobayashi : Proc. Natl. Acad. Sci. U. $S$. A., in press (1988).

(12) K. Sandmann, L. Kroos, S. Cutting, P. Youngman and R. Losick: $J$. Mol. Biol., 200, 461 (1988).

(13) Y. Komeda : J. Bacteriol., 168, 1315 (1986). 